\title{
INTERACTION BETWEEN Baculovirus spodoptera AND NATURAL ENEMIES ON THE SUPPRESSION OF Spodoptera frugiperda (J. E. SMITH) (LEPIDOPTERA: NOCTUIDAE) IN MAIZE
}

\author{
MARIA DE LOURDES CORRÊA FIGUEIREDO ${ }^{1}$, IVAN CRUZ ${ }^{1}$, ANGÉLICA MARIA \\ PENTEADO-DIAS ${ }^{2}$ and RAFAEL BRAGA DA SILVA ${ }^{2}$
}

${ }^{1}$ Embrapa Milho e Sorgo, Caixa Postal 151, CEP 35.701-970, Sete Lagoas, MG, Brasil, E-mail: figueiredomlc@yahoo.com.br,ivancruz@cnpms.embrapa.br

${ }^{2}$ Universidade Federal de São Carlos (UFSCar), Caixa Postal 676, CEP 13.565-905, São

Carlos, SP,Brasil,E-mail: angelica@ufscar.br,rafaelentomologia@yahoo.com.br

$\overline{\text { Revista Brasileira de Milho e Sorgo, v.8, n.3, p. 207-222, } 2009}$

\begin{abstract}
The impact of the application of the Baculovirus spodoptera $\left(2.5 \times 10^{11}\right.$ polyhedra/ha), a nuclear polyhedrosis virus, on maize crop and the possible additional contribution of natural control agents to the management of Spodoptera frugiperda (J. E. Smith) (Lepidoptera: Noctuidae) were evaluated. The experimental design consisted of randomized blocks with seven $B$. spodoptera treatments (at two days application intervals, beginning four days after artificial infestation with fall armyworm egg masses and finishing after 16 days), and five replications. The main natural enemies found in the experimental area were Chelonus insularis (Cresson) (Hymenoptera: Braconidae) and Eiphosoma laphygmae Costa Lima (Hymenoptera: Ichneumonidae), egg/larval and larval parasitoid, respectively, and Doru luteipes Scudder (Dermaptera: Forficulidae), predator of eggs and larvae. Along with NPV, the natural enemies provided a good control of the target insect reducing the damage caused by $S$. frugiperda larvae in maize plants.
\end{abstract}

Key words: biological control, nuclear polyhedrosis virus, parasitoids, predators, fall armyworm. 


\section{INTERAÇÃO ENTRE Baculovirus spodoptera E INIMIGOS NATURAIS NA SUPRESSÃO DE Spodoptera frugiperda (J. E. SMITH) (LEPIDOPTERA: NOCTUIDAE) NA CULTURA DO MILHO}

RESUMO - Foi avaliado o impacto da aplicação do Baculovirus spodoptera (2,5 x $10^{11}$ poliedros/ha) sobre lagartas de Spodoptera frugiperda (J. E. Smith) (Lepidoptera: Noctuidae), e a possível contribuição adicional de seus inimigos naturais na cultura do milho. O delineamento foi em blocos ao acaso com sete tratamentos com B. spodoptera (época de aplicação do inseticida a intervalos de dois dias, iniciando-se quatro dias após a infestação artificial, com posturas de S. frugiperda e finalizando 16 dias após), em cinco repetições. Chelonus insularis (Cresson) (Hymenoptera: Braconidae) e Eiphosoma laphygmae Costa Lima (Hymenoptera: Ichneumonidae), respectivamente, parasitóides de ovo/larva e de larva e o predador de ovos e lagartas, Doru luteipes Scudder (Dermaptera: Forficulidae), foram os principais agentes de controle biológico natural na área. Juntamente com o vírus, os inimigos naturais propiciaram um bom controle do inseto alvo, reduzindo o dano foliar causado pela lagarta nas plantas de milho.

Palavras-chave: controle biológico, vírus da poliedrose nuclear, parasitóides, predadores, lagarta-do-cartucho.

The fall armyworm, Spodoptera frugiperda (J. E. Smith) (Lepidoptera: Noctuidae) is a major maize pest in Brazil, and may infests the crop from plant emergence to harvesting stage. Depending on injury, the pest may cause losses in grain yield up to $55 \%$ (Figueiredo et al., 2006a).

The pest control has been achieved by chemicals, used often in an abusive manner, causing a prompt elimination of the complex of natural enemies in the area and favoring the build-up of resistant populations to these products besides other negative effects on the environment (Cruz, 2002). For these reasons, researchers have been looking for alternative management, such as biological control focusing in mass releasing of natural enemies and/ or protection of the predators and parasitoids through the use of selective insecticides (Lucchini \& Almeida, 1980; Dutcher, 1993; Simões et al., 1998; Figueiredo et al., 1999; Cruz et al., 2002; Cruz, 2002). The importance of predators and parasitoids in association with S. frugiperda has been highlighted not only in 
Brazil (Figueiredo et al., 2006b), but also in other countries (Notz, 1972; Silva et al., 1997; Molina-Ochoa et al., 2004; Murúa et al., 2006, 2009). Entomopathogenic microorganisms, such as the natural occurrence in Brazil of the nuclear polyhedrosis virus (NPV), Baculovirus spodoptera are also considered important in suppressing the pest (Murray et al., 1995; Escribano et al., 1999, 2000; Cruz et al., 2002). The efficiency of a wettable powder formulation in field applications on maize was demonstrated by Cruz et al. (2002). Synergistic effect of the virus and natural biological control agents was reported by Cruz et al. (2002) and Figueiredo et al. (1999).

The objective of this study was to evaluate the application time of the biopesticide $B$. spodoptera on the suppression of $S$. frugiperda in maize and its interaction with the natural enemies of the class Insecta.

\section{Material and Methods}

The study was conducted in Sete Lagoas, Minas Gerais state, Brazil (19 $28^{\prime} 00^{\prime \prime} \mathrm{S}$ and $44^{\circ}$ 15 ' 00 " W), in a savanna region, in the National Maize and Sorghum Research Center (Embrapa / CNPMS), using the maize hybrid BRS 3123.

The effect of a wettable powder formulation of $B$. spodoptera (Nuclear Polyhedrosis Virus - NPV) on maize plant to control the fall armyworm. The virus was applied at a single dose of $2.5 \times 10^{11}$ polyhedra/ ha (50g/ha) (Cruz et al., 1997a) was evaluated using a randomized complete block design with five replications and the treatments were times of virus application at 2-days intervals, since virus application four days after artificial infestation with $S$. frugiperda egg masses (Treatment 1) until virus application 16 days after artificial infestation (Treatment 7). Each plot had six $4 \mathrm{~m}$ long rows (area of $24 \mathrm{~m}^{2}$ ), with 20 plants per row. Plots were kept four meters apart from each other to avoid contamination. Artificial infestation was made fifteen days after plant emergence. Each plot was infested with one egg mass of S. frugiperda on every fifth plant (Cruz \& Turpin, 1983). Egg masses containing about 100 eggs and embryonic development up to 24 hours were selected from a laboratory colony. The virus was applied using a $\mathrm{CO}_{2}$ pressurized backpack sprayer with a flat fan nozzle 8003 , maintaining the pressure to 40 PSI and providing a spray volume equivalent to 300 liters per hectare (Cruz et al., 2002). Of the six rows of each experimental plot three clusters were left to assess the damage caused by pest and to obtain the yield. The other rows were used to quantify the presence of caterpillars and their natural enemies.

Before each insecticide application, 20 plants in a row were picked at random. The same procedure was performed 72 hours after the product application. Plants were cut close to the ground individually placed in plastic bags and taken to the laboratory. Egg masses and/or larvae of $S$. frugiperda were collected 
and counted. Then, egg masses and live larvae were individually transferred to PVC cups $(50 \mathrm{~mL})$ containing artificial diet (Figueiredo et al., 2006b) which were sealed with acrylic cover. Evaluations were made daily to detect the evolution of pest development or the presence of dead insects, and in this case, recording the mortality factor. In each plant it was also evaluated the presence of Doru luteipes Scudder (Dermaptera: Forficulidae), an important predator of eggs and small larvae of $S$. frugiperda, once it is very common in the whorl of maize plants (Cruz \& Oliveira, 1997; Figueiredo et al., 2006ab). In the field, 19 days after infestation, assessments of damage caused by $S$. frugiperda larvae were made in all plots, using the following visual rating scale: 0 - Plants without damaged leaves; 1 - Plants with scraped leaves; 2 - Plants bearing holes in the leaves; 3 - Plants showing leaf damage and some damage to the whorl; 4 - Plants bearing whorl destroyed; 5 - Dead plants (Cruz \& Turpin, 1983). The damage scale was applied to the central leaves of the plant, considering all plants in the plot. At harvest, plant yield was obtained for each plot.

Data of the experiments were analyzed by one-way Analysis of Variance (ANOVA) through the computer program SISVAR (Ferreira, 2000) and treatment means were compared with the Scott-Knott test $(P=0.05)$ (Scott \& Knott, 1974). Before running the ANOVA, tests were conducted to determine if the data set met the necessary assumptions.
Burr-Foster Q and Shapiro-Wilk W tests were used to test equality of variance and normality of the data, respectively, following description found in Anderson \& McLean (1974). Transformation, when applied, was used according to the criteria suggested by Ostle \& Mensing (1975). Regression analyses were also used to determine the relationship between spraying time and larval density, plant infestation, leaf damage and grain yield.

\section{Results and Discussion}

\section{Results}

Prior to the spraying of $B$. spodoptera (Table 1), the number of larvae per plot decreased over time, from 24 caterpillars obtained in the first assessment, to less than three larvae obtained in the last evaluation. Up to eight days after infestation, the relative number of larvae per plot was high, and no significant difference found among the mean number collected from plots taken during this period (three samples). From the fourth sample and thereafter the number of larvae collected per plot was significantly lower (4.4 larvae/ plot on average) than the number obtained in previous assessments.

After virus application, the number of larvae collected at different sampling dates followed a trend similar to that observed prior to application. There was no significant difference among the number of larvae collected in samples taken in the first four samples, with an average 
TABLE 1. Number of larvae, percentage of plants infested by $S$. frugiperda, presence of natural enemies before and 72 hours after spraying with B. spodoptera and leaf damage measured 19 days after infestation (mean $\pm \mathrm{SE}$ ).

\begin{tabular}{|c|c|c|c|c|c|c|c|c|}
\hline \multirow{2}{*}{$\begin{array}{l}\text { Days after } \\
\text { infestation }\end{array}$} & \multicolumn{2}{|c|}{ Larvae/plot ${ }^{1}$} & \multicolumn{2}{|c|}{ Plants with larvae $(\%)^{1}$} & \multicolumn{2}{|c|}{ Parasitism $(\%)^{1}$} & \multirow{2}{*}{$\begin{array}{c}\text { Earwig/ } \\
\text { plot }^{1,2}\end{array}$} & \multirow{2}{*}{$\begin{array}{c}\text { Leaf } \\
\text { damage }^{1}\end{array}$} \\
\hline & $\begin{array}{c}\text { Before } \\
\text { spraying }\end{array}$ & $\begin{array}{l}72 \text { hours after } \\
\text { spraying }\end{array}$ & $\begin{array}{l}\text { Before } \\
\text { spraying }\end{array}$ & $\begin{array}{l}72 \text { hours after } \\
\text { spraying }\end{array}$ & $\begin{array}{l}\text { Before } \\
\text { spraying }\end{array}$ & $\begin{array}{l}72 \text { hours after } \\
\text { spraying }\end{array}$ & & \\
\hline 4 & $24.0 \pm 7 \mathrm{~A}$ & $19.6 \pm 7 \mathrm{~A}$ & $37.5 \pm 5 \mathrm{~A}$ & $55.0 \pm 9 \mathrm{~A}$ & $52.3 \pm 14 \mathrm{~A}$ & $37.4 \pm 37.4 \mathrm{~A}$ & $3.2 \pm 2.3 \mathrm{~B}$ & $0.42 \pm 0.1 \mathrm{~A}$ \\
\hline 6 & $12.5 \pm 3 \mathrm{~A}$ & $12.0 \pm 6 \mathrm{~A}$ & $33.0 \pm 12 \mathrm{~A}$ & $33.0 \pm 8 \mathrm{~A}$ & $43.8 \pm 12 \mathrm{~A}$ & $35.6 \pm 35.6 \mathrm{~A}$ & $3.2 \pm 1.5 \mathrm{~B}$ & $0.68 \pm 0.2 \mathrm{~A}$ \\
\hline 8 & $20.6 \pm 2 \mathrm{~A}$ & $7.4 \pm 4 \mathrm{~A}$ & $43.0 \pm 4 \mathrm{~A}$ & $28.0 \pm 9 \mathrm{~A}$ & $46.6 \pm 6 \mathrm{~A}$ & $27.9 \pm 27.9 \mathrm{~A}$ & $7.0 \pm 2.8 \mathrm{~A}$ & $0.78 \pm 0.3 \mathrm{~A}$ \\
\hline 10 & $6.4 \pm 3 \mathrm{~B}$ & $9.0 \pm 3 \mathrm{~A}$ & $19.0 \pm 7 \mathrm{~B}$ & $19.0 \pm 11 \mathrm{~B}$ & $64.7 \pm 21 \mathrm{~A}$ & $53.5 \pm 53.5 \mathrm{~A}$ & $10.0 \pm 4.5 \mathrm{~A}$ & $0.84 \pm 0.2 \mathrm{~A}$ \\
\hline 12 & $4.0 \pm 1 \mathrm{~B}$ & $1.8 \pm 1 \mathrm{~B}$ & $19.0 \pm 6 \mathrm{~B}$ & $7.0 \pm 1 \quad \mathrm{~B}$ & $57.1 \pm 20 \mathrm{~A}$ & $20.0 \pm 20.0 \mathrm{~A}$ & $11.0 \pm 3.0 \mathrm{~A}$ & $0.78 \pm 0.1 \mathrm{~A}$ \\
\hline 14 & $4.5 \pm 2 \mathrm{~B}$ & $1.7 \pm 1 \mathrm{~B}$ & $12.0 \pm 5 \mathrm{~B}$ & $5.0 \pm 3 \quad \mathrm{~B}$ & $67.2 \pm 18 \mathrm{~A}$ & $33.3 \pm 33.3 \mathrm{~A}$ & $8.0 \pm 2.2 \mathrm{~A}$ & $0.82 \pm 0.2 \mathrm{~A}$ \\
\hline 16 & $2.7 \pm 1 \mathrm{~B}$ & $1.0 \pm 0 \mathrm{~B}$ & $8.0 \pm 6 \quad B$ & $4.0 \pm 1 \quad B$ & & & $12.2 \pm 2.9 \mathrm{~A}$ & $0.82 \pm 0.2 \mathrm{~A}$ \\
\hline
\end{tabular}

${ }^{1}$ Means followed by the same letter in column do not differ significantly according to Scott-Knott test $(\mathrm{P} \leq 0.05)$.

272 hours after spraying with B. spodoptera.

of 12 larvae per plot (Table 1). In the following assessments the number of larvae fell to 1.5 per plot.

The percentage of infested plants (Table 1) occurring before virus application was relatively high in plots sampled four, six and eight days after infestation, with no significant difference among means, which were 37.5, 33 and $43 \%$ respectively. On subsequent assessments, the percentage of infested plants drops to an average of $14.5 \%$ (8 to $19 \%$ ). In the samples taken after virus application, the percentage of plants attacked by fall armyworm was $38.6 \%$ on average, across the first three samples, and no significant difference among means was observed. In the subsequent assessments the percentage of infested plants fell to an average of $8.8 \%$, with no significant difference among means.

The presence of parasitoids in the experimental area was significant. The rate of parasitism (Table 1), in the samples carried out 

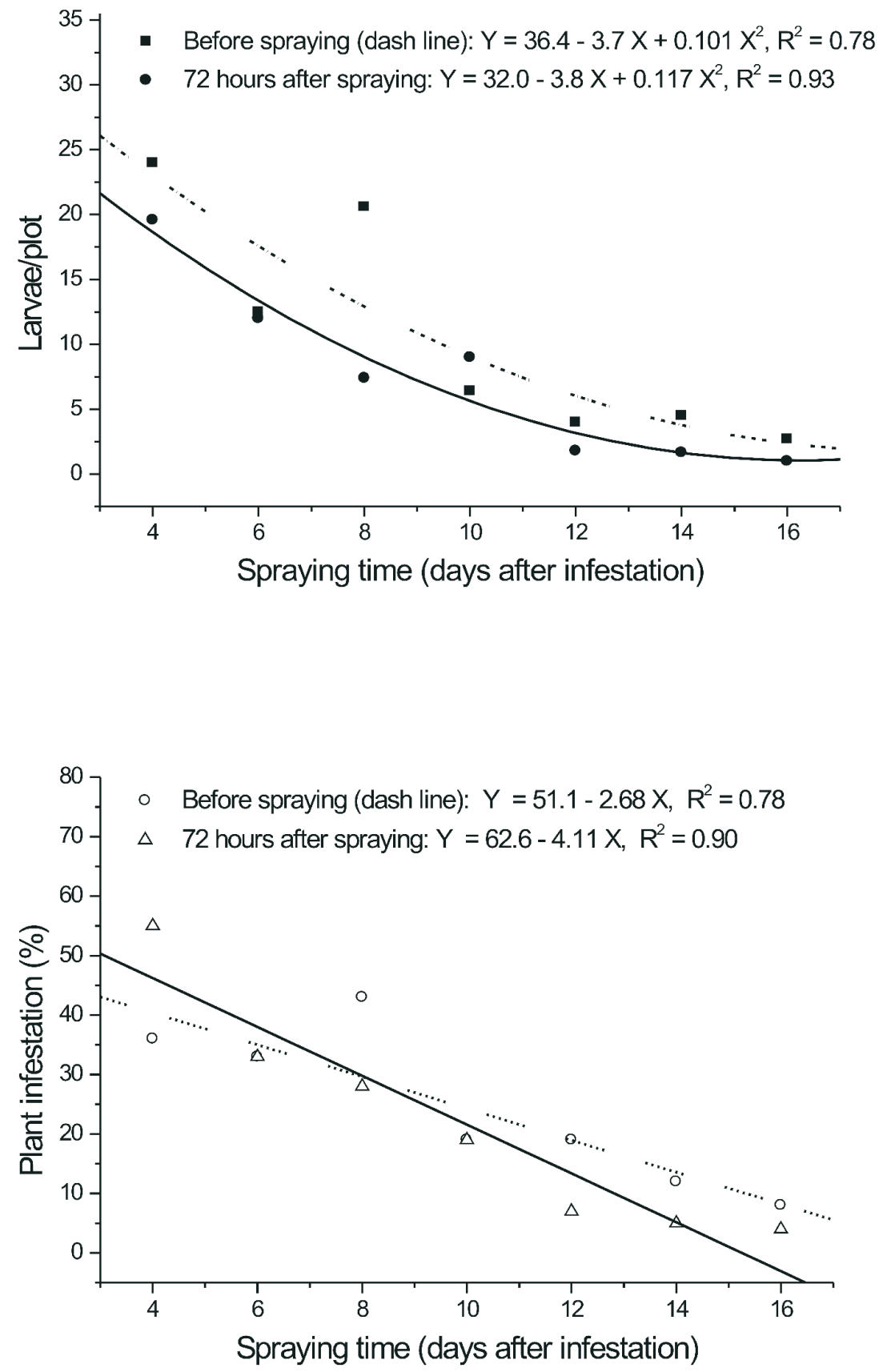

FIGURE 1. Adjusted curve for mean number of larvae and for infestation (\%) of S. frugiperda with samples taken immediately before and 72 hours after application of B. spodoptera. 
before spraying with the virus was $55.3 \%$ on average (43.8 to $67.2 \%$ ), with no significant difference among treatments. Even after spraying the rate of parasitism was still high, and also there was no significant difference among different sampling dates, with an average parasitism rate of $34.7 \%$. Among the parasitoids recovered from collected larvae there was the predominance of only two parasitoids, Chelonus insularis (Cresson) (Hymenoptera: Braconidae) and Eiphosoma laphygmae Costa Lima (Hymenoptera: Ichneumonidae).

In addition to parasitoids, there was a constant presence of the predator of eggs and larvae, the earwig $D$. luteipes, with highest densities in samples taken in more developed plants (Table 1).

\section{Discussion}

The relationship between number of $S$. frugiperda larvae and time was negative and

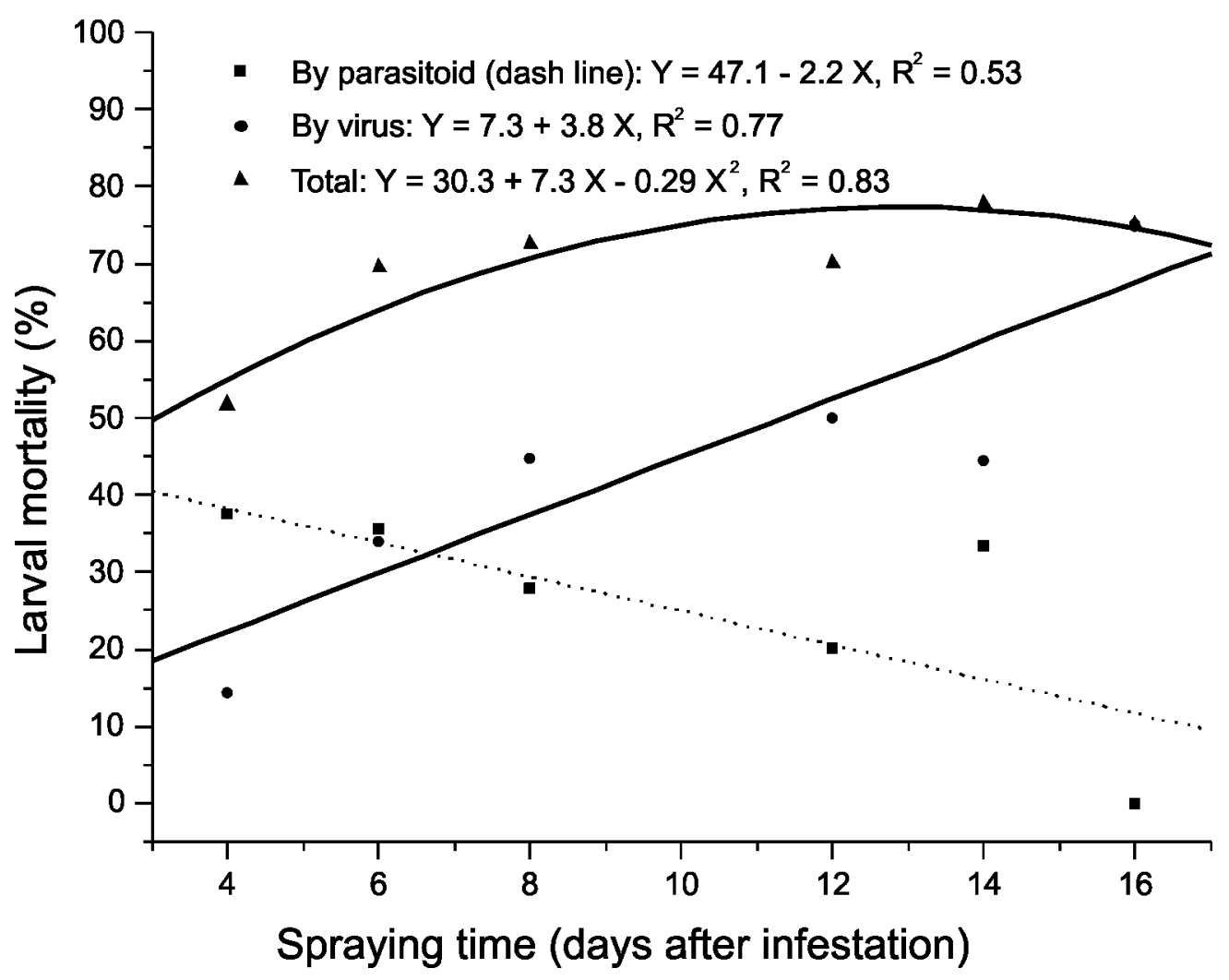

FIGURE 2. Adjusted curve for fall armyworm larval mortality caused by parasitoid and/or virus according to different spraying time of B. spodoptera with samples taken 72 hours after application. 
followed a polynomial model (quadratic) in samples taken before or after virus application (Figure 1). Infestation (\%), on the other hand, followed a negative and linear model.

Reduction in the number of larvae (or infestation level) with the delaying in the time in which the samples were taken can not be attributed to the end of the larval stage of the pest, even on those plots where the samples were taken before virus application and 16 days after infestation (last evaluation period). It is well known that biological cycle of $S$. frugiperda depends mainly on temperature and, within a limit there is a decrease in larval life cycle with the increase of temperature (Cruz, 1995). During the experimental phase the average temperature was $25.3^{\circ} \mathrm{C}$. An average larval cycle of 15 days at a fix temperature of $25^{\circ} \mathrm{C}$ was reported by Busato et al. (2002). Adding a three-days period for egg hatch (Cruz, $1995)$ by the time of the last evaluation, that is, 16 days after infestation, it can be expected that the insects were mostly still in the larval stage. Reduction on number of larvae then could be attributed to cannibalism inherent to the species and/or to biotic factors such as microorganisms and natural enemies (parasitoids and predators). Natural occurrence of larval disease was not verified in collected insect, in samples taken before virus application. However, occurrence of parasitoid in the area was high and constant. Before virus application, from the collected larvae $55.3 \%$ was parasitized. No significant difference was found among treatments (Table
1). Even with the application of virus, parasitism also contributed to suppress the insect pest with an average of $34.5 \%$ parasitism. However, larval mortality due to parasitoid decreased with time (Figure 2). The opposite occurred with the larval mortality caused by virus. In fact, there is a constant and positive relationship between larval mortality caused by both factor and spraying time of virus (Figure 2). According to Escribano et al. (2001) both parasitism and viral infection result in a marked reduction in host growth, specially when third instar fall armyworm larvae are dually parasitized by C. insularis and infected by virus compared to parasitized larvae. On the other hand, although Baculoviruses do not infect natural enemies, there is a possible impact on parasitoids through competitive or indirect effects. Escribano et al. (2000, 2001) reported that the survival of $C$. insularis was not possible in $S$. frugiperda larvae that ingested a lethal dose of NPV during the second, third or early fourth larval instars. Nakai \& Cuc (2005) reported the fate of parasitoids developing within virus infected hosts especially in the case of Chelonus sp. dying during their larval stage before spinning cocoons, or failing to reach adult emergence compared to other parasitoids suggesting that the impact of virus application on the survival of parasitoids varies from species to species.

The parasitoids $C$. insularis and $E$. laphygmae were responsible for 77 and $18.5 \%$ of parasitism in the samples taken before spraying, respectively. The same species parasitoids 


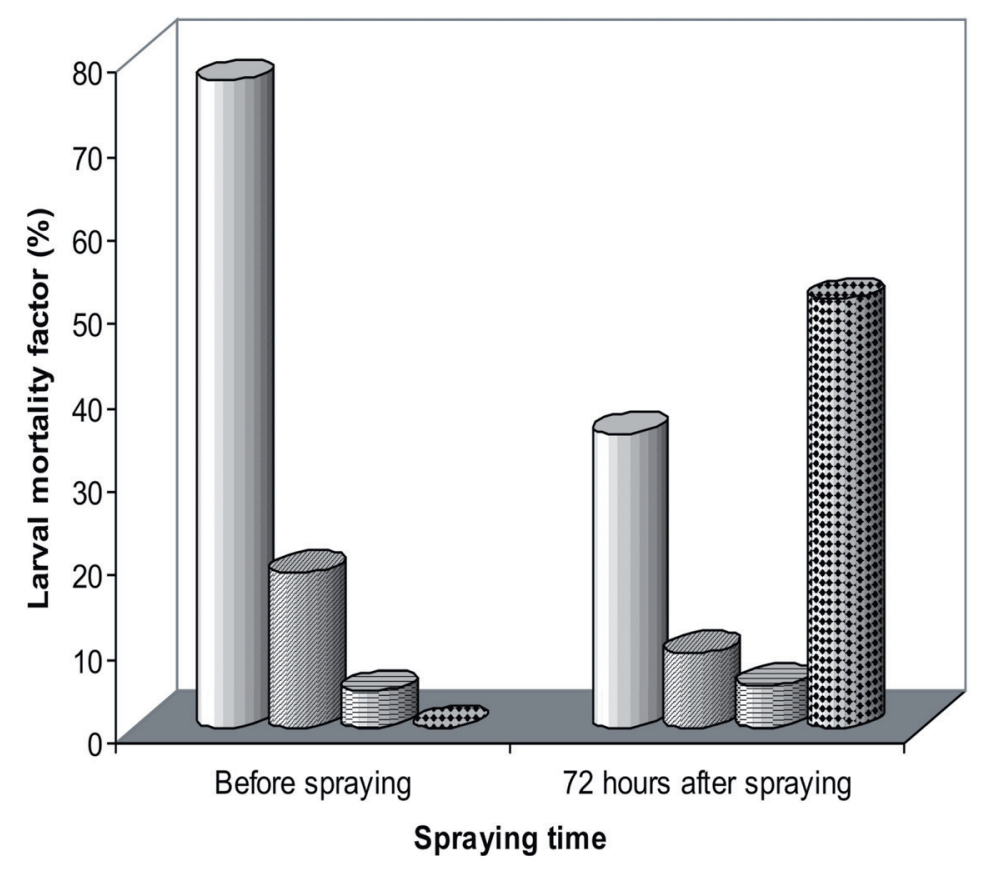

$\square$ Chelonus insularis 圆Eiphosoma laphygmae 目Others 国Baculovirus

FIGURE 3. Causes of mortality of $S$. frugiperda larvae in maize plots observed in samples taken before and 72 hours after application of $B$. spodoptera.

were responsible for 35.1 and $8.9 \%$, after virus application. Virus mortality accounted by $50 \%$ of larval death (Figure 3). The predator of egg and small larvae, D. luteipes was the main species found in the experimental area and also contributed to reduce pest density (Table 1).

The effect of the virus on the larvae of S. frugiperda can be noticed when they appear limp and blackened (Cruz, 1995). The efficiency of the virus tends to decrease with increasing age of larvae (Cruz et al., 2002; Matrangolo et al., 2007). Additional effect of natural enemy could be an important strategy to suppress the population of $S$. frugiperda in maize, considering the specificity of virus. Synergistic effect of virus and natural enemies could be more economic and efficient than the unilateral use of a non-selective chemical pesticide. This is particularly true in the case of $C$. insularis, an egg/larva parasitoid very common in association to $S$. frugiperda in maize field in Brazil (Rezende et al., 1995a; Figueiredo et al., 2006ab).

Once $C$. insularis was the predominant species in the experimental area and due to the fact of parasitism initiate in the host eggs, by the time B. spodoptera was applied, since the 
first virus applications it could be considered an interaction between the two $S$. frugiperda larval mortality factor.

According to Croft \& Brown (1975), in general the effect of pathogens should be considered in similar away to the chemicals. For a parasitoid developing inside a larval host such as $C$. insularis and E. laphygmae it can be distinguished direct and indirect effect of a pathogen over the parasitoid. As a direct effect on the parasitoid through the host and an indirect effect by premature host killing and then causing the death of parasitoid larvae or even alter the physiology of the host so that it is no longer nutritionally suitable for the development of the parasitoid.

Escribano et al. (2000) demonstrated that all $S$. frugiperda larvae ingesting a lethal dose of multiple-enveloped nuclear polyhedrosis virus were unsuitable for $C$. insularis development. The same situation could partially explain the decrease of parasitism by $C$. insularis after virus application (Figure 3), once the parasitoid was still an important mortality factor of $S$. frugiperda larvae. The same tendency seems to be the case of E. laphygmae, a larval parasitoid. According to Murray et al. (1995) the parasitoids Microplitis demolitor Wilkinson (Hymenoptera: Braconidae), Cotesia kazak Telenga (Hymenoptera: Braconidae) and Hyposoter didimator Thunberg (Hymenoptera: Ichneumonidae), required a time advantage of at least three days at $25^{\circ} \mathrm{C}$ before host exposure to a NPV to ensure successful completion of development within Helicoverpa armigera (Hübner) (Lepidoptera: Noctuidae) larvae. The parasitoid Campoletis sonorensis (Cameron) (Hymenoptera: Ichneumonidae) only survive inside $S$. frugiperda larvae when there is a 2-day interval between parasitism and viral infection (Escribano et al., 2000). Matrangolo et al. (2007) evaluating the interaction between the larval parasitoid Campoletis flavicincta Ashmead (Hymenoptera: Ichneumonidae) and virus concluded that the application of the virus to control $S$. frugiperda larvae can adversely affect the parasitism, since the virus can kill the parasitoid larvae developing within the host body. However, according to Vail et al. (1972) even when there is an effect of reducing the rate of parasitism due to application of a NPV, if the overall control is good, one should consider a normal completion between the virus and the parasitoid. And this seems to be the case, and NPV together with the action of $C$. insularis and $E$. laphygmae positively contributed to the reduction of pest population (Figure 2). According to Martínez et al. (2000) S. frugiperda larval mortality induced by virus was approximately 50\% at the highest application rate tested of 1000 larval equivalents (LE) of virus/ha. However, when the impact of parasitism was taken into account, larval mortality increased to 45.0 $90.7 \%$ in plots treated with virus at $250 \mathrm{LE} / \mathrm{ha}$ or more. Cruz et al. (2002) reported an average percentage of larvae killed by the NPV and natural biological control ranging from 88.2 to 

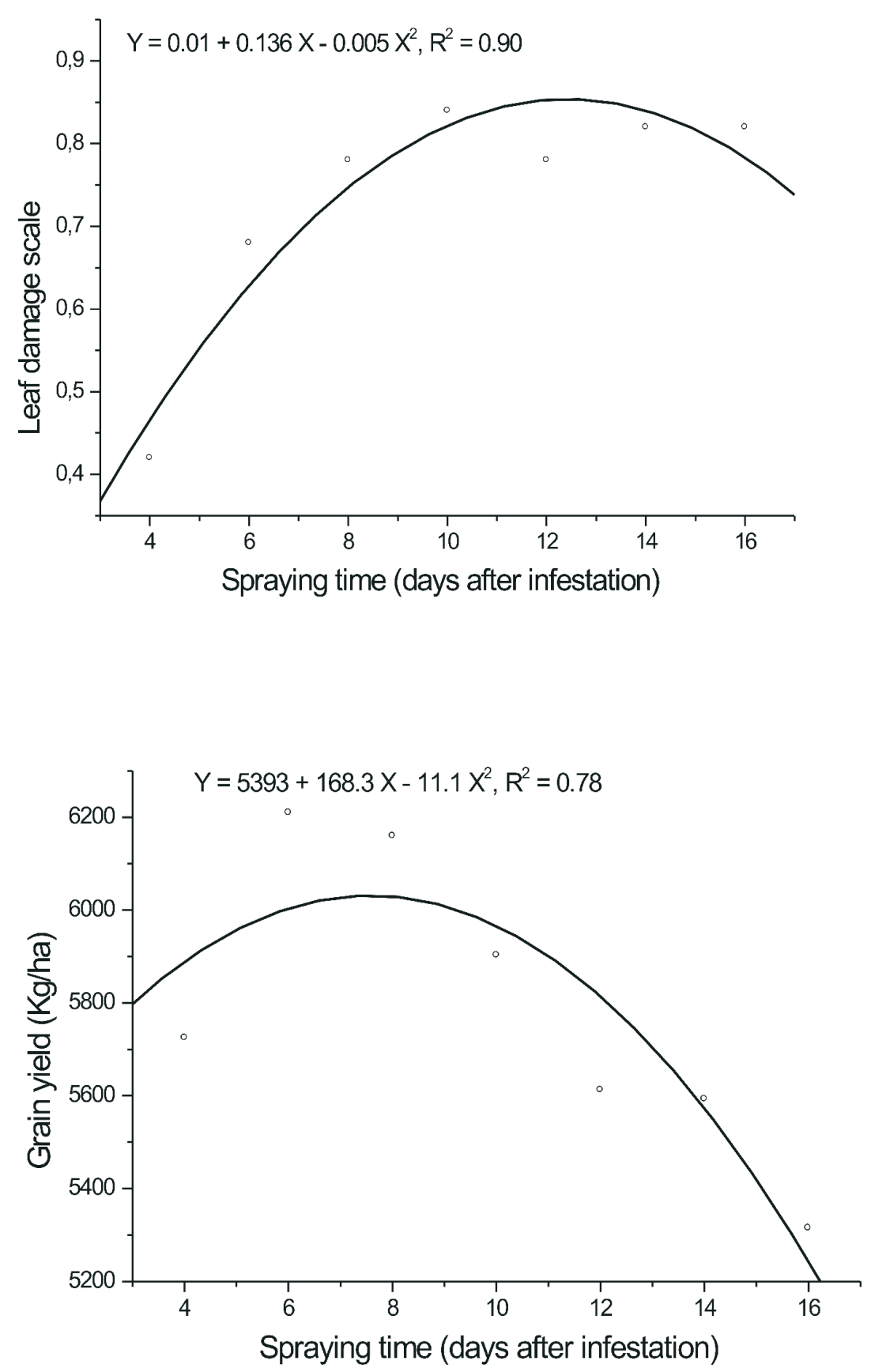

FIGURE 4. Adjusted curve for leaf damage and for maize yield in relation to application time of B. spodoptera. 
96.1\%. Parasitized fall armyworm larvae also reduce significantly the food consumption. For example, larva parasitized by $C$. insularis consumes only $6.8 \%$ of the total maize leaf consumption by a health larva (Rezende et al., 1995b). Similar reduction of food consumption was also verified for NPV infected larva (Cruz, 2000) or for a larval parasitoid such as the $C$. flavicincta (Cruz et al., 1997b).

Obviously, the presence of the earwig also contributed to reduce pest density once it is considered the most important insect predator in association to $S$. frugiperda in Brazil (Cruz \& Oliveira, 1997; Guerreiro et al., 2003; Figueiredo et al., 2006ab) and may consume a large amount of egg and larvae of the insect pest during its life cycle (Reis et al., 1988).

The leaf damage caused by the fall armyworm larvae based in a visual scale from 0 (no damage) to 5 (dead plants) varied 0.42 to 0.82 (Table 1) indicating that the natural presence of parasitoid and predator besides the application of virus were enough to reduces de damage to the plant (Figure 4). According to Cruz \& Turpin (1983) foliar damage has a linear and negative relationship with maize yield. Using the same visual scale, a score close to one was obtained by Figueiredo et al. (1999) in plots where the virus was applied alone or integrated to an egg parasitoid. Cruz et al. (2002) reported an average score of 1.87 on plots infested with larvae and sprayed with
B. spodoptera. The application of microbial agents in infested areas eliminates the insect host, interacts positively with the natural biological control and therefore reduces the damage to maize plants (Hopper \& King, 1984).

In the plots sprayed earlier larvae were smaller, so the consequences of their damage on the plants were lower, giving them a quicker recovery with less effect on yield. Plots with larger larvae and sprayed later, somehow could be expected a reduction on the efficiency of $B$. spodoptera. The maize yield ranged from 5.315 to $6.210 \mathrm{~kg} / \mathrm{ha}$ and there was no significant difference among treatments. However, adjusted curve for maize yield in relation to application time (Figure 4) indicates a tendency to the increases in yield in those plots sprayed earlier, that is, up to eight days after infestation, and a yield reduction after that point.

Considering that there was not statistical difference in maize yield regardless the time in which the virus was applied to suppress the fall armyworm larvae, it can be concluded that the presence of natural enemies in the target area was a positive factor contributing also to reduce pest population.

\section{Acknowledgments}

At the National Research Council (CNPq) for financing part of this work. 


\section{References}

ANDERSON, V. L.; McLEAN, R. A. Design of experiments: a realistic approach. New York: Marcel Deker, 1974. 418 p.

BUSATO, G. R.; GRUTZMACHER, A. D.; GARCIA, M. S.; GIOLO, F. P.; MARTINS, A. F. Consumo e utilização de alimento por Spodoptera frugiperda (J.E. Smith) (Lepidoptera: Noctuidae) originária de diferentes regiões do Rio Grande do Sul, das culturas do milho e do arroz irrigado. Neotropical Entomology, Londrina, v. 31, n. 2, p. 525-529, 2002.

CROFT, B. A.; BROWN, W. A. Responses of arthropod natural enemies to insecticides. Annual Review of Entomology, Palo Alto, v. 20, p. 285-335, 1975.

CRUZ, I. A lagarta-do-cartucho na cultura do milho. Sete Lagoas: EMBRAPA-CNPMS, 1995. 45 p. (EMBRAPA-CNPMS, Circular Técnica, 21).

CRUZ, I. Controle biológico em manejo integrado de pragas. In: PARRA, J. R. P.; BOTELHO, P. S. M.; CORREA-FERREIRA, B. S.; BENTO, J. M. S. (Ed.) Controle biológico no Brasil: Parasitóides e predadores. São Paulo: MANOLE, 2002. p. 543-570.

CRUZ, I. Métodos de criação de agentes entomófagos de Spodoptera frugiperda (J.E. Smith). In: BUENO, V. H. P. Controle biológico de pragas: produção massal e controle de qualidade. UFLA: Lavras, 2000. p. 111-135.
CRUZ, I. Utilização do Baculovírus no controle da lagarta-do-cartucho do milho, Spodoptera frugiperda. In: MELO, I. S.; AZEVEDO, J. L. (Ed.). Controle biológico. Jaguariúna: Embrapa Meio Ambiente, 2000. v. 3, p. 201-230.

CRUZ, I; OLIVEIRA, A. C. Flutuação populacional do predador Doru luteipes Scudder em plantas de milho. Pesquisa Agropecuária Brasileira, Brasília, DF, v. 32, n. 4, p. 363-368. 1997.

CRUZ, I.; TURPIN, F. T. Yield impact of larval infestation of the fall armyworm Spodoptera frugiperda (J.E. Smith) to mid-whorl growth stage of corn. Journal of Economic Entomology, College Park, v. 76, n. 5, p. 10521054, 1983.

CRUZ, I.; FIGUEIREDO, M. L. C; VALICENTE, F. H.; OLIVEIRA, A. C. Application rate trials with a Nuclear Polyhedrosis Virus to control Spodoptera frugiperda (Smith) on maize. Anais da Sociedade Entomológica do Brasil, Jaboticabal, v. 26, n. 1, p. 145-152, 1997a.

CRUZ, I.; FIGUEIREDO, M. L. C.; GONÇALVES, E. P.; LIMA, D. A. N.; DINIZ, E. E. Efeito da idade de lagartas de Spodoptera frugiperda (Smith) (Lepidoptera: Noctuidae) no desempenho do parasitóide Campoletis flavicincta (Ashmead) (Hymenoptera: Ichneumonidae) e consumo foliar por lagartas parasitadas e não parasitadas). Anais da Sociedade Entomológica do Brasil, Jaboticabal, v. 26, n. 2, p. 229-234, 1997 b.

CRUZ, I.; FIGUEIREDO, M. L. C.; OLIVEIRA, A C.; VASCONCELOS, C. A. Damage of 
Spodoptera frugiperda (Smith) in different maize genotypes cultivated in soil under three levels of aluminium saturation. International Journal of Pest Management, London, v. 45, n. 4, p. 293-296, 1999.

CRUZ, I.; GONÇALVES, E. P.; FIGUEIREDO, M. L. C. Effect of a Nuclear Polyhedrosis Virus on Spodoptera frugiperda (Smith) larvae, its damage and yield of maize crop. Revista Brasileira de Milho e Sorgo, Sete Lagoas, v. 1, n. 2, p. 20-27, 2002.

DUTCHER, J. D. Recent examples of conservation of Arthropod natural enemies in agriculture. In: LUMSDEN, R. D.; VAUGHN, J. L. (Ed.). Pest management: biologically based technologies. Washington: American Chemical Society, 1993. p. 101-108.

ESCRIBANO, A.; WILLIAMS, T.; GOULSON, D.; CAVE, R. D.; CHAPMAN, J. W.; CABALLERO, P. Selection of a nucleopolyhedrovirus for control of Spodoptera frugiperda (Lepidoptera: Noctuidae): structural, genetic, and biological comparison of four isolates from the Americas. Journal of Economic Entomology, College Park, v. 92, p. 1079-1085, 1999.

ESCRIBANO, A.; WILLIAMS, T.; GOULSON, D.; CAVE, R. D.; CABALLERO, P. ParasitoidPathogen-pest interactions of Chelonus insularis, Campoletis sonorensis, and a nucleopolyhedrovirus in Spodoptera frugiperda Larvae. Biological Control, San Diego, v. 19, p. 265-273, 2000.
ESCRIBANO, A.; WILLIAMS, T.; GOULSON, D.; CAVE, R. D.; CHAPMAN, J. W.; CABALLERO, P. Consequences of interspecific competition on the virulence and genetic composition of a nucleopolyhedrovirus in Spodoptera frugiperda larvae parasitized by Chelonus insularis. Biocontrol Science and Technology, v. 11, p. 649-662, 2001.

FERREIRA, D. F. Sistema SISVAR para análises estatísticas: manual de orientação. Lavras: Universidade Federal de Lavras/ Departamento de Ciências Exatas, 2000. 37 p.

FIGUEIREDO, M. L. C.; CRUZ, I.; DELLA LUCIA, T. M. C. Controle integrado de Spodoptera frugiperda (Smith \& Abbott) utilizando-se o parasitóide Telenomus remus Nixon. Pesquisa Agropecuária Brasileira, Brasília, DF, v. 34, n. 11, p. 1975-1982, 1999.

FIGUEIREDO, M. L. C.; MARTINS-DIAS, A. M. P, CRUZ, I. Relação entre a lagarta do cartucho e seus agentes de controle biológico natural na produção de milho. Pesquisa Agropecuária Brasileira, Brasília, DF, v. 41, n. 12, p. 1693-1698, 2006a.

FIGUEIREDO, M. L. C.; MARTINS-DIAS A. M. P.; CRUZ, I. Associação entre inimigos naturais e Spodoptera frugiperda (J.E. Smith, 1797) (Lepidoptera: Noctuidae) na cultura do milho. Revista Brasileira de Milho e Sorgo, Sete Lagoas, v. 5, n. 3, p. 340-350, 2006 b.

GUERREIRO, J. C.; BERTI FILHO, E.; BUSOLI, A. C. Ocorrência estacional de Doru luteipes na cultura do milho em São Paulo, Brasil. Manejo Integrado de Plagas y Agroecologia, Costa Rica, v. 70, p. 46-49, 2003. 
HOPPER, K. R.; KING, E. C. Preference of Microplitis croceipes (Hym.: Braconidae) attacking various instars of Heliothis virescens (Lep.: Noctuidae). Environmental Entomology, College Park, v. 15, p. 1145-1150, 1984.

LUCCHINI, F.; ALMEIDA, A. A. Parasitas de Spodoptera frugiperda (Smith \& Abbot 1797) (Lepidoptera: Noctuidae) lagarta do cartucho do milho, encontrados em Ponta Grossa-PR. Anais da Sociedade Entomológica do Brasil, Jaboticabal, v. 9, n. 1, p. 115-121, 1980.

MARTÍNEZ, A. M.; GOULSON, D.; CHAPMAN, J. W.; CABALLERO, P.; CAVE, R. D.; WILliAMS, T. Is it feasible to use optical brightener technology with a baculovirus bioinsecticide for resource-poor maize farmers in Mesoamerica? Biological Control, San Diego, v. 17, p. 174-181, 2000.

MATRANGOLO, W. J. R.; MARTINS-DIAS, A. M. P.; CRUZ, I. Aspectos biológicos de Campoletis flavicincta (Ashmead) (Hymenoptera: Ichneumonidae) e interações com o vírus da poliedrose nuclear de Spodoptera frugiperda. Revista Brasileira de Milho e Sorgo, Sete Lagoas, v. 6, n. 1, p. 1-16. 2007.

MOLINA-OCHOA, J.; CARPENTER, J. E.; LEZAMA-GUTIÉRREZ, R.; FOSTER, J. E.; GONZÁLEZ-RAMÍREZ, M.; ÁNGELSAHAGÚN, C. A.; FARÍAS-LARIOS, J. Natural distribution of hymenopteran parasitoids of Spodoptera frugiperda (Lepidoptera: Noctuidae) larvae in Mexico. Florida Entomologist, Gainesville, v. 87, n. 4, p. 461-472, 2004.
MURRAY, D .A. H.; MONSOUR, C. J.; TEAKLE, R .E.; RYNNE, K. P.; BEAN, J. A. Interactions between nuclear polyhedrosis virus and three larval parasitoids of Helicoverpa armigera (Hubner) (Lepidoptera: Noctuidae). Journal of the Australian Entomological Society, Brisbane, v. 34, n. 4, p. 319-322, 1995.

MURÚA, M. G.; MOLINA-OCHOA, J.; COVIELLA, C. Population dynamics of the fall armyworm, Spodoptera Frugiperda (Lepidoptera: Noctuidae) and its parasitoids in Northwestern Argentina. Florida Entomologist, Gainesville, v. 89, n. 2, p. 175-182, 2006.

MURÚA, M. G.; MOLINA-OCHOA, J.; FIDALGO, P. Natural distribution of larvae of the fall armyworm, Spodoptera frugiperda (Lepidoptera: Noctuidae) and its parasitoids in Northwestern Argentina. Journal of Insect

Sciences, Wisconsin, v. 9, n. 20, p. 1-17, 2009.

NAKAI, M.; CUC, N.T.T. Field application of an insect virus in the Mekong Delta: Effects of a Vietnamese nucleopolyhedrovirus on Spodoptera litura (Lepidoptera: Noctuidae) and its parasitic natural enemies. Biocontrol Science and Technology, v. 15, n. 5, p. 443453. 2005.

NOTZ, P. A. Parasitismo de Diptera e Hymenoptera sobre larvas de Spodoptera frugiperda (Smith) (Lepidoptera - Noctuidae) recolectadas en maiz, Maracay, Venezuela. Revista de la Facultad de Agronomia, Maracay, v. 6, n. 3, p. 5-16, 1972.

OSTLE, B.; MENSING, R.W. Statistics in research. 3 ed. Ames: Iowa State University Press, 1975. 596 p. 
REIS, L. L.; OLIVEIRA, L. J.; CRUZ, I. Biologia e potencial de Doru luteipes no controle de Spodoptera frugiperda. Pesquisa Agropecuária Brasileira, Brasília, DF, v. 23, p. 333-342, 1988.

REZENDE, M. A. A.; CRUZ, I.; DELLA LUCIA, T. M. C. Aspectos biológicos do parasitóide Chelonus insularis (Cresson) (Hymenoptera, Braconidae) criados em ovos de Spodoptera frugiperda (Smith) (Lepidoptera, Noctuidae). Revista Brasileira de Zoologia, Curitiba, v. 12, n. 4, p. 779-784, 1995 a.

REZENDE, M. A. A.; DELLA LUCIA, T. M. C.; CRUZ, I. Comportamento de lagartas de Spodoptera frugiperda (Lepidoptera: Noctuidae) parasitadas por Chelonus insularis (Hymenoptera, Braconidae) sobre plantas de milho. Revista Brasileira de Entomologia, São Paulo, v. 39, n. 3, p. 675-681, 1995 b.

SCOTT, A. J.; KNOTT, M. A. Cluster analysis method for grouping means in the analysis of variance. Biometrics, Washington, v. 30, p. 507-512, 1974.
SILVA, F. M. A.; FOWLER, H. G.; LEMOS, R. N. S. Parasitismo em lagarta-do-cartucho, Spodoptera frugiperda (Smith), na região do Triângulo Mineiro, MG. Anais da Sociedade Entomológica do Brasil, Jaboticabal, v. 26, n. 2, p. 235-241, 1997.

SIMÕES, J. C.; CRUZ, I.; SALGADO, L. $O$. Seletividade de inseticidas às diferentes fases de desenvolvimento do predador Doru luteipes (Scudder) (Dermaptera: Forficulidae). Anais da Sociedade Entomológica do Brasil, Jaboticabal, v. 27, n. 2, p. 289-294, 1998.

VAIL, P. V.; SOO HOO, C. F.; SEAY, R. S.; KILLINEN, R. G.; WOLF, W. W. Microbial control of lepidopterous pests of fall lettuce in Arizona and effects of chemicals and microbial pesticides on parasitoids. Environmental Entomology, College Park, v. 1, n. 6, p.780$785,1972$. 